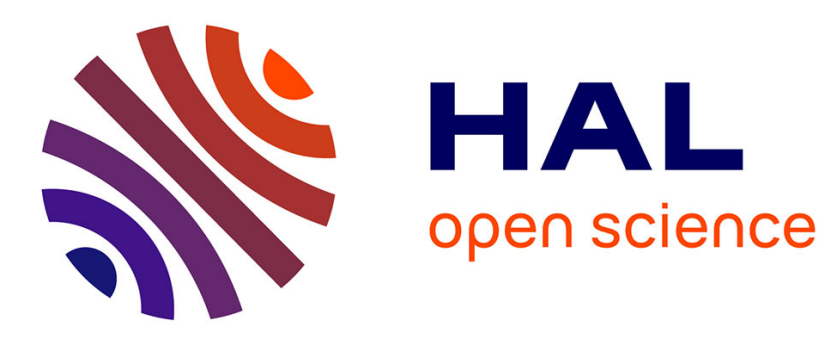

\title{
International credit markets and global business cycles
}

Patrick Pintus, Yi Wen, Xiaochuan Xing

\section{- To cite this version:}

Patrick Pintus, Yi Wen, Xiaochuan Xing. International credit markets and global business cycles. International Journal of Economic Theory, 2019, 15 (1), pp.53-75. 10.1111/ijet.12206 . hal-02075885

\section{HAL Id: hal-02075885 https://hal-amu.archives-ouvertes.fr/hal-02075885}

Submitted on 11 Mar 2020

HAL is a multi-disciplinary open access archive for the deposit and dissemination of scientific research documents, whether they are published or not. The documents may come from teaching and research institutions in France or abroad, or from public or private research centers.
L'archive ouverte pluridisciplinaire $\mathbf{H A L}$, est destinée au dépôt et à la diffusion de documents scientifiques de niveau recherche, publiés ou non, émanant des établissements d'enseignement et de recherche français ou étrangers, des laboratoires publics ou privés. 


\title{
International credit markets and global business cycles
}

\author{
Patrick A. Pintus, ${ }^{*}$ Yi Wen ${ }^{\dagger}$ and Xiaochuan Xing ${ }^{\ddagger}$
}

\begin{abstract}
This paper stresses a new channel through which global financial linkages contribute to the co-movement in economic activity across countries. We show in a two-country setting with borrowing constraints that international credit markets are subject to self-fulfilling variations in the world real interest rate. Those expectation-driven changes in the borrowing cost in turn act as global shocks that induce strong cross-country co-movements in both financial and real variables (such as asset prices, gross domestic product, consumption, investment, and employment). When firms around the world benefit from unexpectedly low debt repayments, they borrow and invest more, which leads to excessive supply of collateral and of loanable funds at a low interest rate, thus fueling a boom both at home and abroad. As a consequence, business cycles are synchronized internationally. Such a stylized model thus offers one way to rationalize both the existence of a world business-cycle component, documented by recent empirical studies through dynamic factor analysis, and the factor's intimate link to global financial markets.
\end{abstract}

Key words world interest rate, international co-movement, self-fulfilling equilibria

JEL classification E21, E22, E32, E44, E63

Accepted 11 October 2018

\section{Introduction}

Empirical evidence suggests that there exists a set of common factors behind business cycles across nations. This set of global factors has affected national outputs of many countries simultaneously over the last 50 years. For example, Kose, Otrok, and Whiteman (2003) document the existence of a distinct world business cycle in a 60-country sample that spans seven regions of the world over the period 1960-90. More specifically, they show that on top of country-specific shocks, a world factor is also important and accounts for a significant fraction of country-specific business-cycle variations. In particular, this global factor accounts for about 35\% of the variances of output and of consumption in the USA, which turns out to be more than the regional or the country-specific factors can explain.

Kose, Prasad, and Terrones (2003) report similar results and further show that financial linkages between countries are more important for international business-cycle transmissions in economies

* CNRS-InSHS and Aix-Marseille University, CNRS-InSHS Délégation Paris Michel-Ange, Paris, France. Email: patrick.pintus@univ.amu.fr

$\dagger$ Federal Reserve Bank of St Louis, St Louis, Missouri, USA and Tsinghua University, Beijing, China.

* Yale University, New Haven, Connecticut, USA.

This article has been written in honor of Roger Farmer, whose intellectual curiosity, academic achievements and generous friendship have both enriched and inspired us. We thank very much Jess Benhabib, Kazuo Nishimura, and Makoto Yano for inviting us to contribute to this special issue, as well as a referee for comments and suggestions and Stéphane Auray for discussions. The usual disclaimer applies. 
that are more open to international capital flows (see also Imbs 2004). More recently, Crucini et al. (2011) also confirm that the world-wide business cycle is as important as the nation-specific business cycles and they also find that "real interest rates are dominated by a common G-7 component, with two-thirds of the variance attributable to the common factor and almost none attributed to the nation-specific component" (p. 167). In other words, in G7 countries real interest rates exhibit variations that appear to be driven by a common global factor. Therefore, not only do national levels of output and consumption follow a world component, but so also do financial variables.

In sum, the existing body of empirical evidence strongly points to the existence of a few world common factors that explain international co-movements of both output and financial variables. In addition, financial linkages between countries through international capital and debt markets are suspected to play a key role in explaining these common factors. Of striking importance is the fact that a common component drives much of the co-movement in different countries' interest rates, at least in developed economies.

However, little is known theoretically about the nature of such common factors behind world real output and financial variables, uncovered through dynamic factor analysis in the studies reviewed above. One obvious candidate is global technology shocks. But the hypothesized existence of global technology shocks suffers from the lack of micro-level empirical evidence that innovations at the firm level are synchronized globally despite different institutional arrangements, such as patent laws and government efforts to protect technological secrets. It is not obvious that different countries' technology frontiers progress and regress at the same time.

International trade is another possible source of global business cycle propagation (see, for example, Miyamoto and Nguyen 2017). But it takes time for goods and services to move across borders: shipping time often takes weeks if not months from one country to another. So the role of shocks to the speed of global shipping or trade costs in generating the world business cycle is also likely to be limited.

This paper proposes that the existence of a global financial market sets the condition for the rise of financial and real global factors that cause global business cycles. We show how the existence of a global financial market makes it possible for investors' expectations to be coordinated around the world. In particular, global sentiments originating from the world financial market can simultaneously drive both global interest rates and national outputs across the world. Intuitively, financial markets are connected much more tightly and in a more timely manner across nations than goods and labor markets, yet within each country the goods and labor sectors are closely connected to the financial sector. As a result, animal spirits in the world financial market can simultaneously affect the financial and real variables in each country (especially across developed economies, which are more financially globalized).

Thus, we develop a very simple setting with two countries that are open to international financial capital flows, within which cross-national credit borrowing and lending operate under collateral constraints to alleviate defaults. We deliberately assume that production factors such as labor, land, and capital are not mobile across national borders to highlight the role of global financial linkages in generating global real business cycles.

More specifically, we assume that in each country households are international lenders and firms are international borrowers, through a global bond market, under the standard assumption that the former are more patient than the latter (à la Kiyotaki and Moore 1997). Although borrowing and lending are channeled through a world financial market, production factors in each country cannot be traded across countries. In other words, in each country firms (households) can borrow (lend) internationally (subject to a collateral constraint) and the world interest rate on financial debt adjusts to reflect the tightness of the global supply and demand for loans. 
We show that in this setting expectations about the future world real interest rate are self-fulfilling. As a result, sunspot/belief shocks to the world interest rate can simultaneously cause movements in asset prices, output, consumption, employment, and investment to go in the same direction in all countries. In other words, the optimistic/pessimistic views about the world interest rate can generate global credit expansion/contraction, so that countries' outputs, consumption, labor and capital investment co-move. Key to our results is the endogenous response of credit supply to credit demand that renders the real interest rate counter-cyclical - a stylized fact and a long-standing puzzle in the existing literature (see, for example, Boldrin et al. 2001; Pintus et al. 2016). In contrast, we show that country-specific shocks to productivity or leverage do not induce co-movement across countries in output and other key aggregates, unless strong direct (spill-over) effects are assumed. This is because an expansion in the home economy due to, say, an increase in productivity, raises the world interest rate, which in turn hurts the foreign economy.

\subsection{Related literature}

This paper contributes to the literature on open-economy extensions of the seminal analysis in Kiyotaki and Moore (1997); see also Iacoviello (2005), Pintus and Wen (2013), Liu et al. (2013), and Pintus et al. (2016). In particular, we extend the small-open-economy settings of, among others, Kocherlakota (2000), Pintus and Wen (2013), and Kaas et al. (2016) by considering a two-country model. The reason why self-fulfilling equilibria arise in our two-country model is essentially similar to that detailed in the closed-economy version with variable interest rate studied in Pintus et al. (2016). In a nutshell, expectations about the world interest rate can be self-fulfilling because they move credit supply and demand in the same direction. When the interest rate is not predetermined, a lower than expected repayment triggers a rise in demand for credit and collateral from the borrower, as well as an increase in collateral and extended loans by the lender. Both our papers build upon and extend the seminal analysis in Benhabib and Farmer (1994) on self-fulfilling equilibria in standard businesscycle theory by introducing credit market frictions and global financial linkages. In addition, we use the technique proposed by Farmer et al. (2015) to solve for the model with local indeterminacy.

Several papers emphasize that business cycles spread internationally through the channel of international trade. For instance, in a perfect-foresight trade model, Nishimura and Yano (1993) compare the correlation of the endogenous real business cycles in trading countries before and after the opening up of trade. In a model with sector-specific externalities, Nishimura et al. (2010) investigate the interlinkages in the business cycles of two countries and its welfare implications when self-fulfilling prophecies arise in a free-trade equilibrium. In contrast, our emphasis on global financial linkages in explaining international co-movements accords with the existence of a global financial cycle documented in particular by Miranda-Agrippino and Rey (2015), in addition to the studies using dynamic factor analysis reviewed above. Differently, earlier explanations of international co-movements rely on productivity shocks that are highly correlated across countries, as in Backus and Kehoe (1992) and Backus et al. (1995). More recently, Kollman (2018) shows in a complete-market two-country model with Epstein-Zin-Weil preferences and a muted wealth effect that country-specific productivity shocks generate synchronized business cycles. In contrast, the recent evidence and our paper place international financial markets center-stage to explain how financial spill-over effects help synchronize business cycles across countries.

Our paper also belongs to the literature on financial frictions and self-fulfilling equilibria. Liu and Wang (2014) show that the financial multiplier due to credit constraints shifts resources among firms with heterogeneous productivity, leading to endogenous aggregate total factor productivity 
(TFP) and increasing returns at the aggregate level. He et al. (2015) study consumption loans secured by houses. They show how endogenous volatility in prices arises because housing conveys liquidity. Azariadis et al. (2016) focus on unsecured loans for which repayment incentives come from the value of reputation. In such a setting, they show that self-fulfilling equilibria exist because borrowers' expectations of future credit market conditions affect their current reputation value, which in turn determines current credit constraints. Our paper differs from the above in studying entrepreneurs' secured borrowing activity and focusing on the equilibrium multiplicity stemming from the interaction between variable interest rate and entrepreneurs' borrowing constraints.

The remainder of this paper is organized as follows. Section 2 sets the stage by presenting the two-country model, while Section 3 compares international business cycles driven by either countryspecific or global shocks. Section 4 presents some concluding remarks. Additional results are gathered in Appendix A.

\section{Two-country model}

\subsection{Description}

The world economy is divided into two countries, home and foreign, that are each composed of households/lenders and entrepreneurs/borrowers. We assume that installed capital, land and labor are internationally immobile. To save space, we report below the problems faced by each agent in the home country only, given that the foreign country has an identical structure. All variables marked with an asterisk are related to the foreign economy, while those without refer to the home country.

Production technology is given, in each period $t$, by

$$
Y_{t}=A_{t} K_{t}^{\alpha} L_{t}^{\gamma} N_{t}^{1-\alpha-\gamma}
$$

where $K_{t}$ denotes capital, $L_{t}$ is land, and $N_{t}$ is worked hours. Total land supply is fixed and given by $\bar{L}$, with country-specific price $Q_{t}$.

The entrepreneur, who takes care of production, hires labor in the domestic market with wage rate $W_{t}$, and accumulates both productive capital and productive land. He participates in an international bond market where a one-period bond is exchanged, which earns the gross rate $R_{t+1}^{w}$ that will be realized at date $t+1$. Under the assumption that the entrepreneur is more impatient than the household, he turns out to be a borrower near steady state. The entrepreneur's bond demand is denoted by $B_{e, t+1} \cdot{ }^{1}$ Finally, the entrepreneur enjoys consuming $C_{e, t}$ in each period. The borrowing firm solves the problem

$$
\max _{\left\{C_{e, t}, K_{t+1}, L_{e, t+1}, B_{e, t+1}, N_{t}\right\}_{t=0}^{\infty}} \mathbb{E}_{0}\left[\sum_{t=0}^{\infty} \beta_{e}^{t} \frac{C_{e, t}^{1-\sigma_{b}}}{1-\sigma_{b}}\right]
$$

under the budget constraint

$$
C_{e, t}+K_{t+1}-(1-\delta) K_{t}+Q_{t}\left(L_{e, t+1}-L_{e, t}\right)+R_{t}^{w} B_{e, t} \leq B_{e, t+1}+Y_{t}-W_{t} N_{t}
$$

1 For the sake of parsimony, we use indices $h$ and $e$ only for variables that differ across households and entrepreneurs in equilibrium. For example, since production comes from entrepreneurs only, $Y_{t}$ is not indexed by " $e$." Similarly, $N_{t}$ refers to hours worked in equilibrium. 
as well as the collateral constraint

$$
\mathbb{E}_{t}\left[R_{t+1}^{w}\right] B_{e, t+1} \leq \Theta_{t} \mathbb{E}_{t}\left[Q_{t+1}\right] L_{e, t+1},
$$

which says that expected debt repayment cannot exceed a fraction $\Theta_{t}$ of the market value of land that is expected to materialize next period.

Denoting by $\Lambda_{e, t}$ and $\Phi_{e, t}$ the Lagrange multipliers associated with firm's budget constraint (2) and collateral constraint (3), respectively, the following set of equations gives the firm's first-order conditions for interior solutions:

$$
\begin{aligned}
C_{e, t}^{-\sigma_{b}} & =\Lambda_{e, t}, \\
\Lambda_{e, t} Q_{t} & =\Phi_{e, t} \Theta_{t} \mathbb{E}_{t}\left[Q_{t+1}\right]+\beta_{e} \mathbb{E}_{t}\left[\Lambda_{e, t+1}\left(\gamma \frac{Y_{t+1}}{L_{e, t+1}}+Q_{t+1}\right)\right], \\
\Lambda_{e, t} & =\beta_{e} \mathbb{E}_{t}\left[\Lambda_{e, t+1}\left(\alpha \frac{Y_{t+1}}{K_{t+1}}+1-\delta\right)\right], \\
\Lambda_{e, t} & =\beta_{e} \mathbb{E}_{t}\left[\Lambda_{e, t+1} R_{t+1}^{w}\right]+\Phi_{e, t} \mathbb{E}_{t}\left[R_{t+1}^{w}\right], \\
W_{t} & =(1-\alpha-\gamma) \frac{Y_{t}}{N_{t}}
\end{aligned}
$$

Each country also has a representative household, which derives utility from consumption $C_{h, t}$ and land holding $L_{h, t}$. The household supplies labor $N_{t}$, which entails some loss in utility. It supplies labor to the domestic market and has access to the international bond market so as to transfer consumption across time. The household's demand for international bonds is given by $B_{h, t+1}$.

Because the household is more patient than the entrepreneur in each country (i.e. $\beta_{h}>\beta_{e}$ ), it acts as a lender and solves

$$
\max _{\left\{C_{h, t}, L_{h, t+1}, B_{h, t+1}, N_{t}\right\}_{t=0}^{\infty}} \mathbb{E}_{0}\left[\sum_{t=0}^{\infty} \beta_{h}^{t}\left(\frac{C_{h, t}^{1-\sigma_{l}}}{1-\sigma_{l}}+\psi \frac{L_{h, t}^{1-\sigma_{w}}}{1-\sigma_{w}}-\zeta \frac{N_{t}^{1+\eta}}{1+\eta}\right)\right],
$$

subject to the budget constraint

$$
C_{h, t}+Q_{t}\left(L_{h, t+1}-L_{h, t}\right)+B_{h, t+1}+\frac{\phi}{2}\left(B_{h, t+1}-B_{e, t+1}\right)^{2} \leq R_{t}^{w} B_{h, t}+W_{t} N_{t} .
$$

Note that land enters the household's utility, and in the budget constraint (9) there appears a quadratic holding cost, the size of which is parameterized by $\phi$. This quadratic cost is expressed in terms of the net foreign asset position (or surplus), which we will denote by $S_{t}=B_{h, t}-B_{e, t}$. Whenever $S_{t}$ is positive (negative), this means that the home economy is lending to (borrowing from) the foreign economy. Of course, in that case the foreign counterpart $S_{t}^{*}$ is negative (positive). Similarly, if the deviation of $S_{t}$ from steady state is positive (negative), then either the home country's lending goes up (down) or its borrowing goes down (up). The response of the foreign economy's net foreign asset position is again the mirror image of the home economy's.

The main reason why we include a quadratic cost in terms of the net foreign asset position is to make the model stationary. Absent this cost (i.e. if $\phi=0$ ), the model's dynamic system has a unit root which comes from the fact that the steady-state net foreign asset position in each country is indeterminate. In such a case, the model determines only the world demand for bonds but not how 
it is split between countries. A unit root in our two-country setting is neither new nor surprising since there is only one world interest rate that equalizes the demand and supply of bonds at the world level, not within countries. A similar picture arises in the two-country model of, for example, Baxter and Crucini (1995). We set $\phi=0.0001$ throughout, so that the quadratic cost is negligible for all practical purposes. $^{2}$

Therefore, the household's first-order conditions are given, assuming interior solutions, by

$$
\begin{aligned}
C_{h, t}^{-\sigma_{l}} & =\Lambda_{h, t}, \\
\Lambda_{h, t} Q_{t} & =\beta_{h} \mathbb{E}_{t}\left[\psi L_{h, t+1}^{-\sigma_{w}}+\Lambda_{h, t+1} Q_{t+1}\right], \\
\Lambda_{h, t}\left[1+\phi\left(B_{h, t+1}-B_{e, t+1}\right)\right] & =\beta_{h} \mathbb{E}_{t}\left[\Lambda_{h, t+1} R_{t+1}^{w}\right], \\
\Lambda_{h, t} W_{t} & =\zeta N_{t}^{\eta}
\end{aligned}
$$

where $\Lambda_{h, t}$ is the Lagrange multiplier associated to the budget constraint (9). Note that the firstorder condition with respect to international bond demand (Equation (12)) also holds in the foreign country. This implies, because the world interest rate is common to both countries, that a unit root arises in the dynamics of the ratio of home and foreign consumptions when there is no cost of holding a non-zero foreign asset position (i.e. when $\phi=0$ ). ${ }^{3}$

Given that

$$
S_{t+1} \equiv B_{h, t+1}-B_{e, t+1},
$$

we have that national net exports are

$$
X_{t} \equiv Y_{t}-C_{h, t}-C_{e, t}-I_{t}-\frac{\phi}{2} S_{t+1}^{2}
$$

The above definitions and relations apply symmetrically to the foreign country.

The market clearing condition for land is

$$
\bar{L}=L_{e, t+1}+L_{h, t+1} \text {. }
$$

In addition, the international debt market clears when

$$
B_{h, t+1}+B_{h, t+1}^{*}=B_{e, t+1}+B_{e, t+1}^{*},
$$

2 Schmitt-Grohé and Uribe (2003) set $\phi=0.00074$ to ensure stationarity in a small-open-economy model. Both their value for $\phi$ and ours therefore imply a negligible net foreign asset holding cost. The main function of the holding cost is to pin down a well-defined steady state, not to account for business cycle variances. Our qualitative and quantitative results are not sensitive to different parameter values of $\phi$. Particularly, $\phi$ is not crucial for the model's endogenous persistence, because it is associated with an eigenvalue greater than or equal to 1 : when $\phi$ is zero, the model has a unit eigenvalue, while a slightly positive $\phi$ makes the corresponding eigenvalue larger than 1 to satisfy the Blanchard-Kahn conditions. Similar results with different values for $\phi$ are not presented to save space but are available upon request.

3 To see this, set $\phi=0$ and log-linearize Equation (12) as well as its foreign analog around the steady state, which gives $c_{h, t}-c_{h, t}^{*}=\mathbb{E}_{t}\left[c_{h, t+1}-c_{h, t+1}^{*}\right]$, where $c_{h, t}$ denotes the deviation of $\log C_{h, t}$ from the steady state. 
or equivalently $S_{t+1}+S_{t+1}^{*}=0$, while Walras' law implies that the world output market clears as well, that is,

$$
C_{e, t}+C_{h, t}+C_{e, t}^{*}+C_{h, t}^{*}+\frac{1}{2} \phi\left(B_{h, t+1}-B_{e, t+1}\right)^{2}+\frac{1}{2} \phi^{*}\left(B_{h, t+1}^{*}-B_{e, t+1}^{*}\right)^{2}+I_{t}+I_{t}^{*}=Y_{t}+Y_{t}^{*},
$$

where $I_{t}=K_{t+1}-(1-\delta) K_{t}$ denotes investment net of capital depreciation. This also implies that net exports are equal to the current account (i.e. $S_{t+1}-S_{t}$ minus the interest income from the net foreign asset position $\left.\left(R_{t}^{w}-1\right) S_{t}\right)$, that is,

$$
X_{t}=S_{t+1}-R_{t}^{w} S_{t}=-\left(S_{t+1}^{*}-R_{t}^{w} S_{t}^{*}\right)=-X_{t}^{*} .
$$

The equilibrium allocation is described by the set of variables

$$
\left\{Y_{t}, C_{e, t}, C_{h, t}, L_{e, t+1}, L_{h, t+1}, K_{t+1}, B_{e, t+1}, B_{h, t+1}, S_{t+1}, X_{t}, N_{t}, \Lambda_{e, t}, \Lambda_{h, t}, \Phi_{e, t}, Q_{t}, W_{t}\right\}_{t=0}^{\infty}
$$

for home and

$$
\left\{Y_{t}^{*}, C_{e, t}^{*}, C_{h, t}^{*}, L_{e, t+1}^{*}, L_{h, t+1}^{*}, K_{t+1}^{*}, B_{e, t+1}^{*}, B_{h, t+1}^{*}, S_{t+1}^{*}, X_{t}^{*}, N_{t}^{*}, \Lambda_{e, t}^{*}, \Lambda_{h, t}^{*}, \Phi_{e, t}^{*}, Q_{t}^{*}, W_{t}^{*}\right\}_{t=0}^{\infty}
$$

for foreign, while $\left\{R_{t}^{w}\right\}_{t=0}^{\infty}$ is the world interest rate. Those 33 variables solve home and foreign versions of Equations (1)-(16) and the international debt market clearing condition (17).

\subsection{Self-fulfilling equilibria}

The purpose of this section is to extend the proof in Pintus et al. (2016), obtained in a closedeconomy setting, to show that steady-state indeterminacy arises also in our two-country setting. This happens when loans are such that the interest rate that applies to current debt repayment is variable (i.e. not predetermined). More specifically, a simple model with closed-form solutions is used to derive analytical results that are amenable to intuition. The setting is essentially a linear and simplified version of the model developed above: there is no capital and no labor, a linear technology transforms land into output, and the lender has linear utility. In addition, we abstract from the above quadratic cost for further simplicity.

In the simplified model, the budget constraint of the representative lender is now

$$
C_{h, t}+Q_{t}\left(L_{h, t+1}-L_{h, t}\right)+B_{h, t+1} \leq R_{t}^{w} B_{h, t},
$$

while the instantaneous utility function of the lender is given by $C_{h, t}+\psi L_{h, t}$. In other words, we assume that $\sigma_{l}=\sigma_{w}=0$. In addition, a representative borrower produces goods using land and the linear technology given by $Y_{t}=A L_{e, t}$, while his budget constraint is now given by

$$
C_{e, t}+Q_{t}\left(L_{e, t+1}-L_{e, t}\right)+R_{t}^{w} B_{e, t} \leq B_{e, t+1}+A L_{e, t}
$$

An important feature of the budget constraint is that debt repayment is not predetermined in period $t$, as the endogenous interest rate adjusts to fundamental and possibly self-fulfilling shocks. ${ }^{4}$ The

4 Under the chosen timing, the liability of the entrepreneur in period $t$ is $R_{t}^{w} B_{e, t}$, as opposed to $R_{t-1}^{w} B_{e, t}$. That is, the interest payment generated by the outstanding debt stock $B_{e, t}$ is subject to changes in the current market interest rate in period $t$, when the debt repayment is due. Many financial debt contracts such as adjustable-rate mortgage contracts use a variable interest rate, such as the LIBOR rate plus a markup. The proportion of variable rate debt contracts is significant in practice; for example, Vickery (2008) shows that $70 \%$ of lines of credit in the Survey of Small Business Finance database are variable-rate. 
per-period utility function of the representative borrower is given by $\log C_{e, t}$ (i.e. $\sigma_{b}=1$ ). Finally, the borrowing faced by the borrower is still given by Equation (3), with $\Theta_{t}=\Theta$ now supposed to be constant over time.

The model just described turns out to have closed-form solutions. More specifically, assuming $A=1$ and $\Theta=1$, the first-order conditions of the lender imply that the land price is constant over time, $Q=\beta_{e} /\left(1-\beta_{h}\right)$, while the expected interest rate is constant too, $\mathbb{E}_{t} R_{t+1}^{w}=\beta_{h}^{-1}$. In addition, the binding credit constraint gives $B_{e, t+1}=\beta_{h} Q L_{e, t+1}$, which once plugged into the borrower's budget constraint gives

$$
C_{e, t}+Q\left(1-\beta_{h}\right) L_{e, t+1}=X_{t} L_{e, t},
$$

where $X_{t} \equiv 1+Q\left(1-\beta_{h} R_{t}^{w}\right)$ represents the borrower's return on land net of interest payment. It is then easy to show that, due to logarithmic utility, the borrower's consumption and land demand have closed-form solutions given by $C_{e, t}=\left(1-\beta_{e}\right) X_{t} L_{e, t}$ and $L_{e, t+1}=X_{t} L_{e, t}$. On the other hand, the lender's first-order condition boils down to $\mathbb{E}_{t} R_{t+1}^{w}=\beta_{h}^{-1}$. It follows that self-fulfilling equilibria are simply constructed as solutions to $L_{e, t+1}=\left[1+Q\left(1-\beta_{h} R_{t}^{w}\right)\right] L_{e, t}$ and $\beta_{h} R_{t}^{w}=1+\varepsilon_{t}$, where the innovation $\varepsilon_{t}$ is any independent and identically distributed (i.i.d.) random variable with zero mean, given initial value $L_{0}>0$. In this simple setup, sunspot innovations $\varepsilon_{t}$ originate from forecasting errors on the interest rate. This means that such a simple economy with variable (non-predetermined) interest rate can be globally indeterminate so that interest rate expectations are self-fulfilling in both the home and the foreign economies.

In contrast, it is easy to see that steady-state determinacy holds when the interest rate is predetermined. By this we mean that the borrower's budget and credit constraints are now

$$
\begin{gathered}
C_{e, t}+Q\left(L_{e, t+1}-L_{e, t}\right)+R_{t-1}^{w} B_{e, t} \leq B_{e, t+1}+A L_{e, t}, \\
R_{t}^{w} B_{e, t+1} \leq Q L_{e, t+1},
\end{gathered}
$$

while the lender's budget constraint is

$$
C_{h, t}+Q\left(L_{h, t+1}-L_{h, t}\right)+B_{h, t+1} \leq R_{t-1}^{w} B_{h, t},
$$

so that the interest repayment due in period $t$ is now predetermined, while the interest rate that enters the credit constraint is variable but now known in period $t$. It is then easy to show that the interest rate is constant over time, that is, $R_{t}^{w}=\beta_{h}^{-1}$, so that $X_{t}=1$ at all dates and the economy is forever in steady state, absent fundamental shocks, hence not subject to self-fulfilling shocks.

Returning to the case of loans with a non-predetermined interest rate, the simple model described above is useful to get an intuitive sense of why self-fulfilling equilibria arise. To do so, let us to derive credit demand and credit supply at the world level. Credit demand, originating from the home and foreign economies, can be derived from the binding credit constraints, that is,

$$
B_{t+1}^{d}=\beta_{h} Q\left[L_{e, t+1}+L_{e, t+1}^{*}\right]
$$




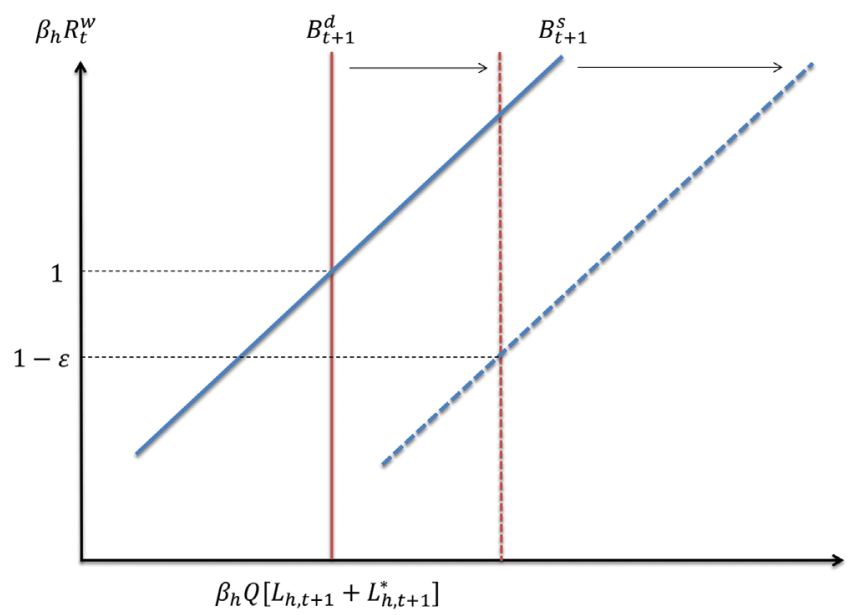

Figure 1 Both credit demand $B^{d}$ and credit supply $B^{s}$ shift rightward when borrowers expect a fall in interest rate and invest more in land so that $L_{e, t+1}+L_{e, t+1}^{*}$ goes up, resulting in a self-fulfilling fall in $R_{t}^{w}$.

where $L_{e, t+1}+L_{e, t+1}^{*}$ represents total land in the hands of borrowers/producers at the world level. On the other hand, manipulating the lender's budget constraint and taking into account that world consumption equals world output, it is straightforward to get that world credit supply is given by

$$
B_{t+1}^{s}=Q\left[L_{e, t+1}+L_{e, t+1}^{*}\right]-\beta X_{t}\left[L_{e, t}+L_{e, t}^{*}\right]
$$

and both are conveniently depicted in Figure 1. Now suppose that borrowers around the world expect the interest rate to go down. They increase their consumption and land investment $L_{e, t+1}+L_{e, t+1}^{*}$ so that credit demand shifts rightward in Figure 1. In addition to being a shifter of credit demand through the collateral channel (see (25)), $L_{e, t+1}+L_{e, t+1}^{*}$ is also a shifter of credit supply through land reallocation to the borrowers (see (26)). As can be seen from Figure 1, the net effect is a fall in the interest rate. This is because, in view of Equations (25) and (26), the credit supply curve shifts to the right by more than the credit demand curve when $L_{e, t+1}+L_{e, t+1}^{*}$ goes up: when the borrowers' land demand goes up by $\Delta\left[L_{e, t+1}+L_{e, t+1}^{*}\right]$, the lenders' land holdings go down by the same amount since land is in fixed supply in each country, which means that total lenders' savings in the form of lending go up by $Q \Delta\left[L_{e, t+1}+L_{e, t+1}^{*}\right]$. On the other hand, borrowers' credit demand goes up by $\beta_{h} Q \Delta\left[L_{e, t+1}+L_{e, t+1}^{*}\right]$, that is, by a little less since the loan-to-value ratio is smaller than 1 . The bottom line is that the interest rate goes down and the initial expectation is fulfilled. In other words, the interest rate is counter-cyclical in the indeterminate model with variable-rate loans. In contrast, this cannot happen in the economy with predetermined interest rate, which stays in the steady state forever, absent fundamental shocks, because the interest rate is constant through time.

\section{International business cycles}

The purpose of this section is to contrast the impulse responses arising in the model developed in Section 2.1, under country-specific (fundamental) shocks and under global (expectation-driven) interest rate shocks. More specifically, we assume that country-specific shocks happen under two 
Table 1 Parameter values

\begin{tabular}{ccccccccccccccc}
\hline$\alpha$ & $\gamma$ & $\delta$ & $\beta_{h}$ & $\beta_{e}$ & $\sigma_{l}$ & $\sigma_{w}$ & $\sigma_{b}$ & $\psi$ & $\eta$ & $\zeta$ & $\phi$ & $\bar{L}$ & $A$ & $\Theta$ \\
\hline 0.4 & 0.05 & 0.025 & 0.99 & 0.98 & 1 & 1 & 1 & 1 & 10 & 1 & 0.0001 & 1 & 1 & 0.8 \\
\hline
\end{tabular}

guises. The home country experiences a positive shock to either TFP $(A)$ or the loan repaymentto-value ratio $(\Theta$, leverage for short), where both variables are assumed to follow an $\mathrm{AR}(1)$ process with autocorrelation set to 0.95 for the sake of illustration. Notice that these two shocks to the home country have no direct (spill-over) effect on the foreign economy by construction (i.e. they are not correlated across countries).

In contrast, we define a global sunspot shock as a self-fulfilling one-time reduction in the world interest rate $(R)$, which by definition means that the cost of borrowing internationally goes down for both home and foreign firms. ${ }^{5}$ Importantly, even though the shock to the world interest rate has no exogenous persistence, the model generates endogenous persistence that is commensurate with that under persistent fundamental shocks.

A second dimension of our simulation exercises is that we compare symmetric and asymmetric countries. In the former case, both the home and the foreign economies share the exact same parameter values, which we report in Table 1 . In the asymmetric case, we simply assume that the collateral constraint is tighter in the foreign economy that is otherwise similar to the home economy, and we report the impulse responses to country-specific and global shocks.

The main lesson to draw from this section is that global sunspot shocks channeled through the international credit market are much more conducive to co-movement across countries than country-specific shocks. This is because country-specific shocks that trigger an expansion in the home economy also raise the world interest rate, which adversely affects the foreign economy. In contrast, worldwide expectations of a falling interest rate generate an expansion in both regions of the world, which then co-move.

\subsection{Symmetric countries}

Our benchmark calibration for the home economy appears in Table 1. In this section, we focus on the case where the foreign economy's parameters are also given by values reported in Table 1 and the countries are said to be symmetric.

Many parameter values in Table 1 are standard for a quarterly calibration. The share of capital is set to 0.4 while the share of land equals 0.05 , which together imply that the share of labor income is 0.55 . Capital depreciation is set to $2.5 \%$ while the quarterly interest rate equals $1 \%$, given that $\beta_{h}=0.99$. In addition, the borrower is only moderately more impatient than the lender, with $\beta_{e}=0.98$. We focus on $\log$ utility and assume that the Frisch elasticity of labor supply is 0.1 , in agreement with many micro studies. Finally, the loan repayment to value ratio $\Theta$ is set at 0.8 , which means that the entrepreneur is able to borrow up to $80 \%$ of the market value of his land holdings.

5 As in Pintus et al. (2016), today's interest rate is not uniquely pinned down and there is one-dimensional indeterminacy. Such indeterminacy comes from the fact that loans feature a variable rate, as emphasized in Section 2.2 using a simplified setting. The model is numerically solved by using the technique proposed by Farmer et al. (2015), which entails a "fundamental" forecast error $\varepsilon_{t}$ such that $R_{t}^{w}=E_{t-1} R_{t}^{w}+\varepsilon_{t}$. 

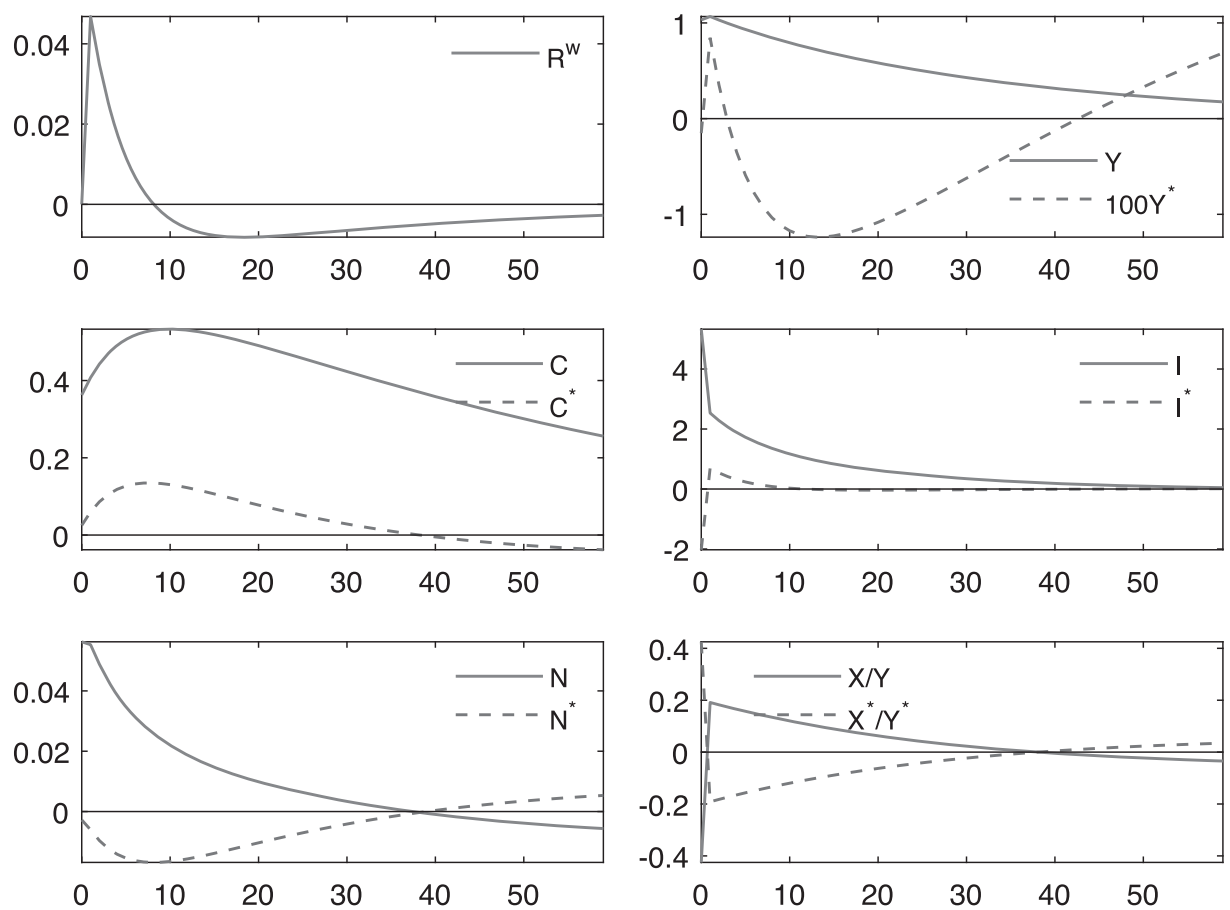

Figure 2 IRFs to a positive TFP shock in home economy: symmetric countries (home, solid lines; foreign, grey lines).

\section{Responses to country-specific shocks}

We show first that country-specific shocks (either a positive TFP shock or a relaxation of the borrowing constraint) cannot generate world-wide co-movements in all key variables. In the following graphs, the solid lines represent the home economy while the grey lines denote the foreign responses.

When countries are symmetric, temporary country-specific TFP shocks have very persistent effects, as can be seen in Figure 2. Additional impulse-response functions (IRFs) are reported in Figure A1 in the Appendix. But the home and foreign economies do not co-move along some key variables, such as output, investment and labor. This is because the boom in the home economy generated by rising productivity raises the world interest rate, which adversely affect the foreign economy in the absence of technological spill-over effects.

When the home entrepreneur benefits from higher TFP, his demand for capital, land and labor goes up, which in turn raises the price of land and the wage. The combination of a higher land price and holding more land implies that the entrepreneur has more collateral, thus raising his demand for credit. In sum, because at home land is reallocated toward production, entrepreneurs accumulate more capital and households work harder, output goes up. A boom in household consumption also follows because of a strong income effect from a higher return on savings, just as would happen in a closed economy. However, in our two-country setting, the home economy has access to a global credit market and the rise in home demand for international bonds pushes the interest rate up next period (see Figure 2). ${ }^{6}$ In the foreign economy, the rise in tomorrow's interest rate generates a

6 Note that because the interest rate is subject to belief shocks, it becomes predetermined and fundamental shocks affect today's expectations of tomorrow's interest rate. 

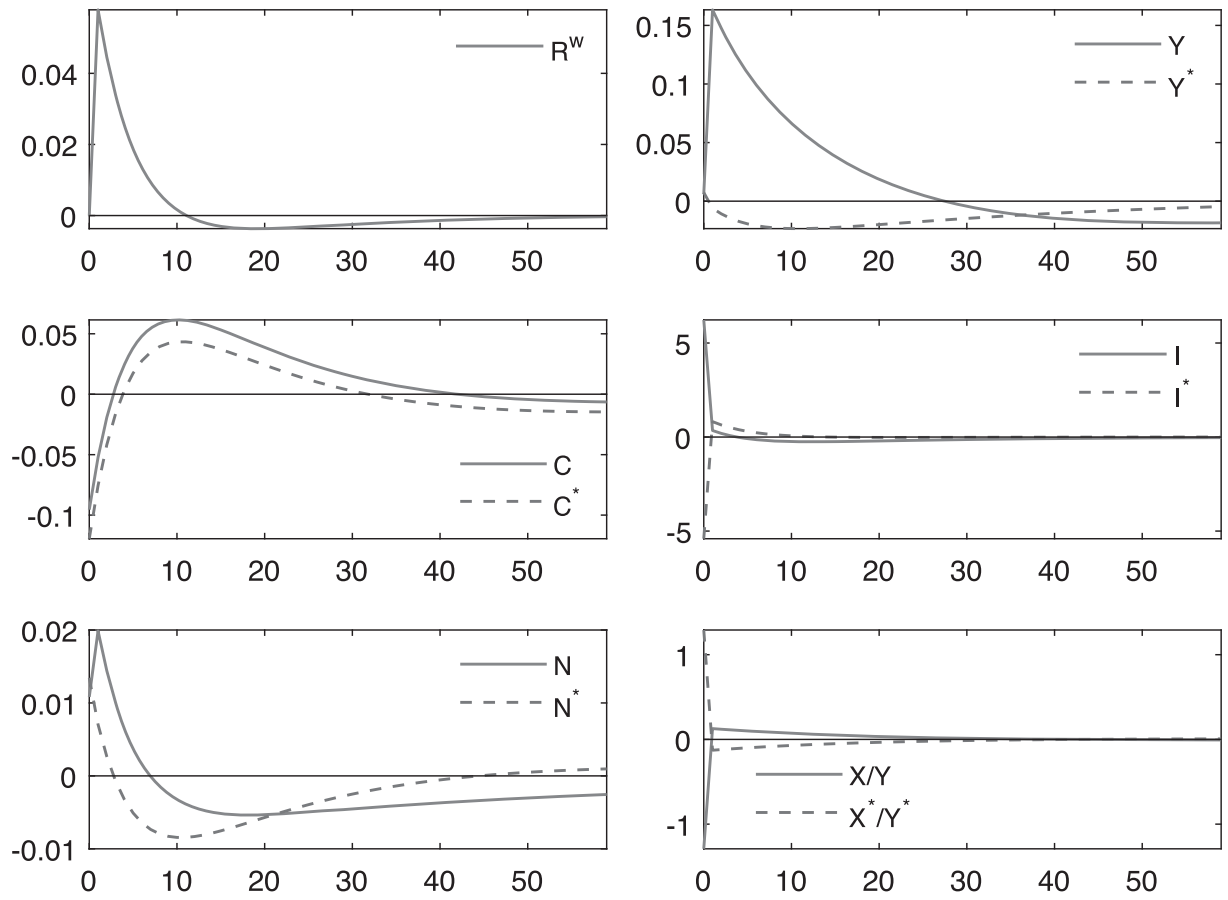

Figure 3 IRFs to a positive leverage shock in home economy: symmetric countries (home, solid lines; foreign, grey lines).

positive income effect on the household/lender. Being richer and facing a rising return on lending, the household consumes more, works less (which pushes the wage up), and lends more. In contrast, a rising interest rate and a rising wage both hurt the entrepreneur in the foreign economy, who reduces investment and faces a decreasing labor supply. Therefore, output falls in the foreign economy. ${ }^{7}$

As a consequence, initially, part of the boom in the home economy is financed by the foreign economy since the home net foreign asset position is reduced. This is consistent with the fact that financial resources initially flow into the home economy since it is more productive. However, pretty soon the home economy ends up with a trade surplus and a rising net foreign asset position. The reason is that while foreign households initially supply more loanable funds, this pattern is quickly reversed because both the wage income and the bond return overshoot their steady-state levels. In terms of co-movement, consumption in the home and foreign economies moves in the same direction, at least during a few quarters after the positive TFP shock hits the home economy, both for households and for entrepreneurs. Similarly, land prices co-move across countries. However, national outputs, labor supplies and investment levels do not co-move.

Similarly, when countries are structurally symmetric and the home economy benefits from a temporary relaxation of the collateral constraint, key variables do not co-move, as shown in Figure 3. Specifically, while consumption co-moves across countries, just as the land price does, home and foreign outputs are negatively correlated. Essentially, when the collateral constraint is relaxed in the

7 Note that because households are willing to lend more in the foreign economy, the land market adjusts and land is reallocated to the entrepreneur, just as in the home economy. As a consequence, a one-period boom in output materializes before a long-lasting recession in the foreign economy. 

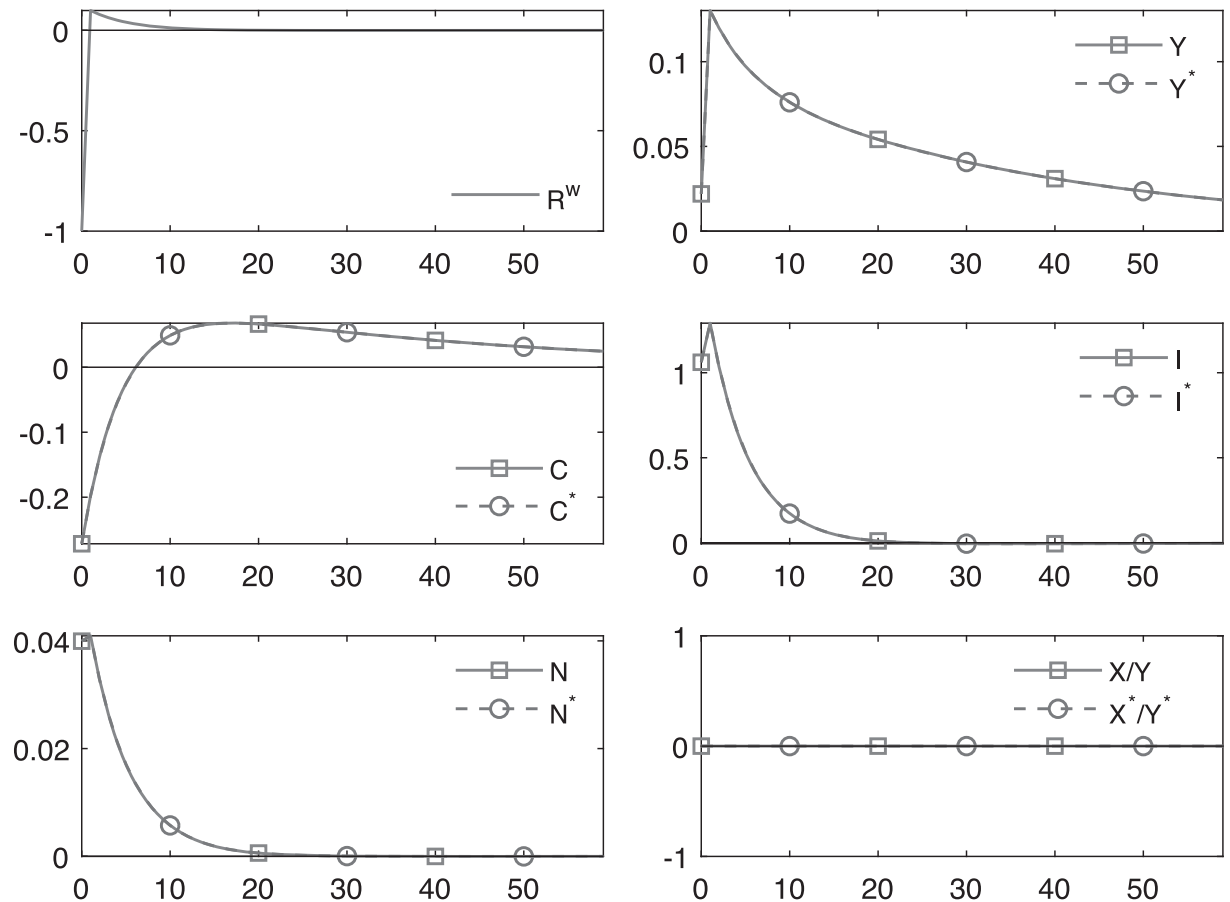

Figure 4 IRFs to a negative shock to the world interest rate: symmetric countries (home, solid lines; foreign, grey lines).

home economy, the entrepreneur borrows more and produces more. As in the case of a positive TFP shock, the associated credit boom in the home economy raises the world interest rate (see Figure 3 ). This again hurts the foreign economy. In contrast with the case of the TFP shock, however, labor supplies now co-move but wages move in opposite direction. ${ }^{8}$

\section{Responses to global interest rate shocks}

In contrast to what happens under country-specific TFP or leverage shocks, the responses of the home and the foreign economies coincide under a sunspot shock to the world interest rate, as shown in Figure 4. In other words, all variables in the home and foreign economies co-move, except of course net foreign asset positions and net exports.

This is because a self-fulfilling reduction in the interest rate means that the cost of borrowing is lowered for both home and foreign firms. As a consequence, the demand for loans by entrepreneurs goes up all around the world. Note that the supply of loans from households accommodates demand

8 Another difference is that the land price goes down on impact under a positive leverage shock, as shown in Figure A2. This is required because the credit constraint is relaxed when $\Theta$ goes up. Specifically, both the demand curve and the supply curve for land shift downward. From the borrower's perspective, the land price reflects both the collateral value and the payoff value (production value and resale value), as described in Equation (5). When the borrowing constraint is relaxed, the collateral value of land decreases, which shifts the demand curve for land downward. From the perspective of the lender, higher credit demand from the borrower pushes up the interest rate. So the lender reduces investment in land and extends loans, which shifts the supply curve of land downward. The above two effects combine to lower the land price and to reallocate land from the lender to the borrower. 
Table 2 International correlations between symmetric countries (simulations for 10,000 periods)

\begin{tabular}{lcccc}
\hline & $\operatorname{Corr}\left(Y, Y^{*}\right)$ & $\operatorname{Corr}\left(C, C^{*}\right)$ & $\operatorname{Corr}\left(I, I^{*}\right)$ & $\operatorname{Corr}\left(N, N^{*}\right)$ \\
\hline Home TFP shock (model) & -0.10 & 0.25 & -0.28 & -0.81 \\
Home leverage shock (model) & -0.48 & 0.88 & -0.94 & 0.48 \\
Global interest rate shock (model) & 1.00 & 1.00 & 1.00 & 1.00 \\
US - Eurozone (data) & 0.66 & 0.67 & 0.62 & n.a. \\
US - Canada (data) & 0.78 & 0.52 & 0.77 & 0.43 \\
\hline
\end{tabular}

despite a fall in consumption (and an increase in labor supply) after impact because consumption goes up later. The resulting credit boom in both economies is accompanied by a reallocation of land away from households and towards entrepreneurs, which results in a declining land price (see Figure A3). Because entrepreneurs borrow more, they accumulate more land and capital and they also benefit from a larger labor supply. Therefore, output goes up in both countries by the same amount since countries are symmetric and face the same reduction in the world interest rate. Last but not least, notice that although the shock to the world interest rate has no built-in persistence, its propagation mechanism generates considerable persistence endogenously. In fact, the effect of an i.i.d. interest rate forecast error is at least as persistent as the effect of a highly autocorrelated shock to TFP or leverage.

In addition, while the interest rate turns out to be counter-cyclical under sunspot shocks, as in the data, it is pro-cyclical under either TFP or leverage shocks. Note that when today's interest rate turns
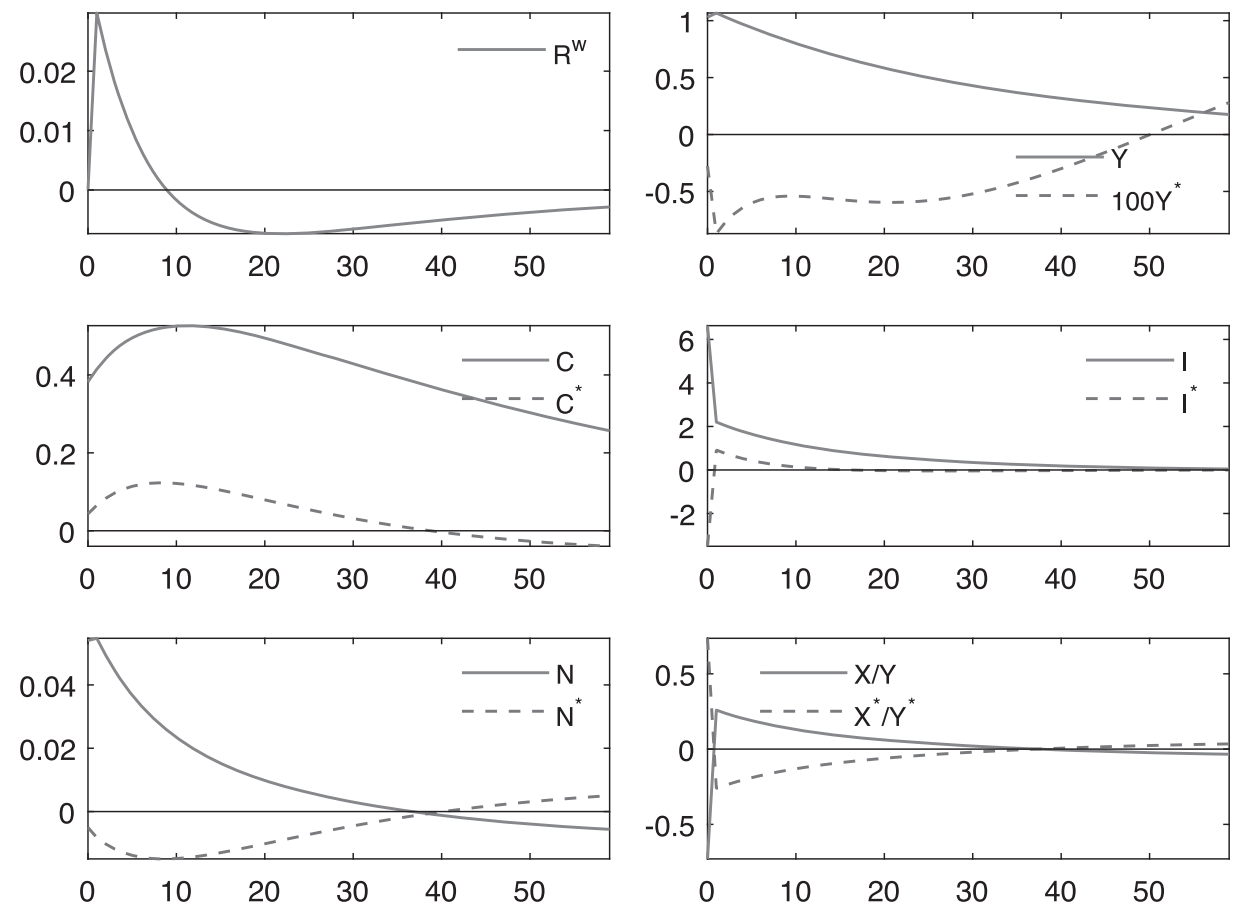

Figure 5 IRFs to a positive TFP shock in home economy: asymmetric countries (home, solid lines; foreign, grey lines). 

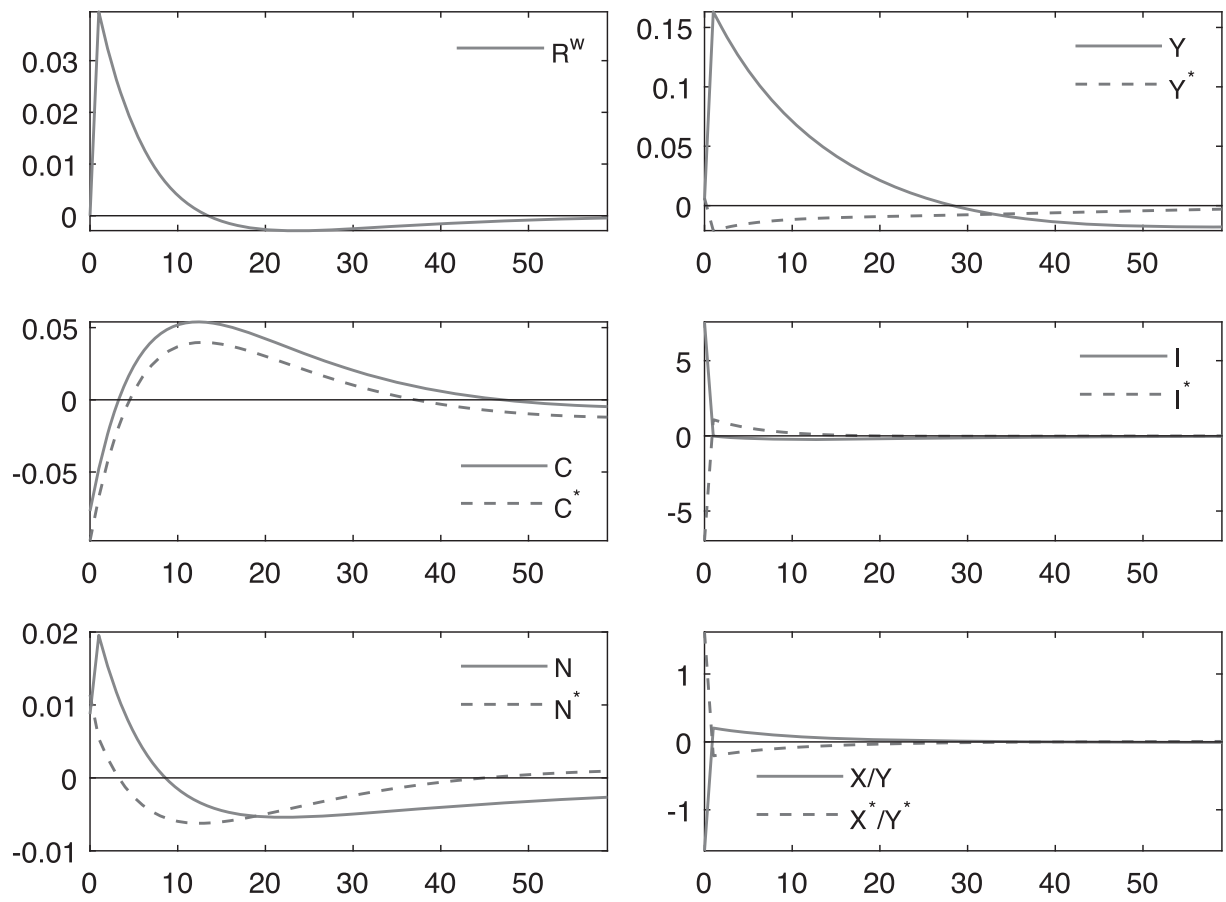

Figure 6 IRFs to a positive leverage shock in home economy: asymmetric countries (home, solid lines; foreign, grey lines).

out to be lower than expected previously, both home and foreign firms expect a higher borrowing rate starting tomorrow, as shown in Figure 4, which is required for lenders to be willing to extend credit today.

The main result from the IRFs reported in this section, therefore, is that country-specific shocks to TFP or leverage do not generate co-movement in output, investment and many other variables across economies. In contrast, global sunspot shocks to the world interest rate do. ${ }^{9}$ This is further illustrated in Table 2, in which we report in the first three rows the cross-country contemporaneous correlations obtained from stochastic simulations of the model, under the three sources of disturbances. The last two rows in Table 2 also show the correlations obtained from the data, which are all positive. ${ }^{10}$ Table 2 suggests that global interest shocks play a key role, in our model, to explain the empirical fact that output levels co-move internationally.

\subsection{Asymmetric countries}

In this subsection we assume that countries have different $\Theta$ s in steady state, thus reflecting different levels of internal financial development, which are, however, not too dissimilar (think about two

9 Note also that country-specific shocks generate a credit boom that is short-lived in the foreign economy. As a result, cross-country correlation of debt is much weaker than under global interest rate shocks.

10 We use quarterly data for output, consumption, and investment in G7 countries, from 1996Q1 to 2018Q2, as well as annual data for hours, 1950-2014. Each time series is downloaded from the FRED database, and empirical correlations in Table 2 are based on Hodrick-Prescott-filtered, log-level data. 

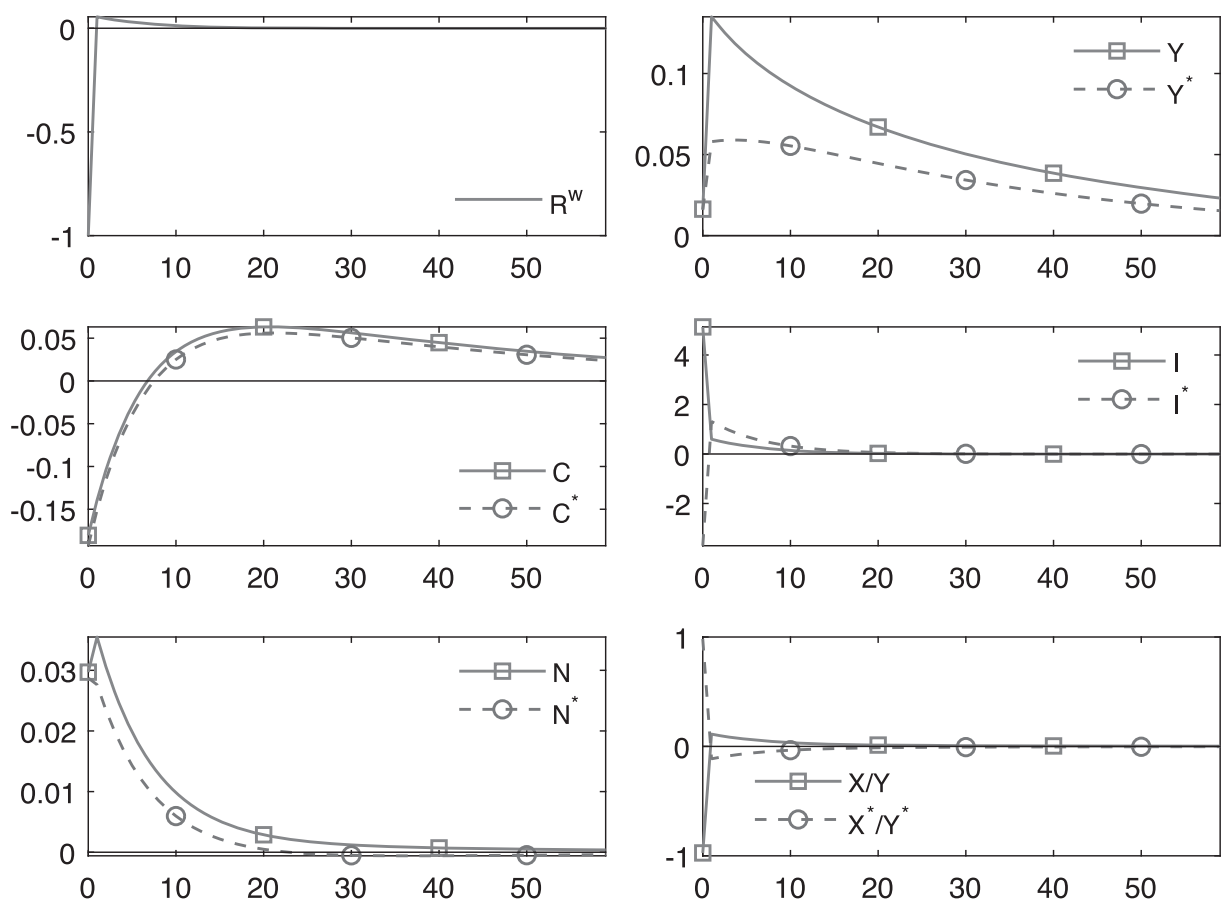

Figure 7 IRFs to a negative shock to the world interest rate: asymmetric countries (home, solid lines; foreign, grey lines).

developed economies). More precisely, countries are now asymmetric, and, while the home economy's parameters are still given by Table 1 (with, in particular, $\Theta=0.8$ ), the foreign economy's $\Theta^{*}=0.6$. In other words, foreign firms face a tighter borrowing constraint. Note that in the graphs reported below, the solid lines represent the home responses while the grey lines denote the foreign responses.

\section{Responses to country-specific shocks}

The IRFs to a positive TFP shock hitting the home economy, reported in Figure 5, do not differ much from those in the symmetric case (see Figure 2). Differently, though, the recession in the foreign economy is now more brutal and more persistent. See Figure A4 for IRFs of additional variables. Similarly for responses to a positive leverage shock in the home economy (contrast Figure 6 with Figure 3): the recession in the foreign economy is more brutal (see also Figure A5). In a nutshell, country-specific shocks do not make all key variables in both economies co-move, especially for output and investment, when countries are asymmetric. This turns out to be the case despite the fact that, on impact, a credit boom happens simultaneously at home and in the foreign economy.

\section{Responses to global interest rate shocks}

As in the symmetric case, both countries still co-move when they are asymmetric, albeit now not perfectly (see Figure 7). More specifically, after the world interest rate falls, the responses of almost all variables are larger in the home economy since it is now more leveraged than the foreign country. 
Table 3 International correlations between asymmetric countries (simulation for 10,000 periods)

\begin{tabular}{lcccr}
\hline & $\operatorname{Corr}\left(Y, Y^{*}\right)$ & $\operatorname{Corr}\left(C, C^{*}\right)$ & $\operatorname{Corr}\left(I, I^{*}\right)$ & $\operatorname{Corr}\left(N, N^{*}\right)$ \\
\hline Home TFP shock (model) & -0.12 & 0.22 & -0.43 & -0.81 \\
Home leverage shock (model) & -0.70 & 0.90 & -0.96 & 0.42 \\
Global interest rate shock (model) & 0.99 & 0.99 & -0.67 & 0.98 \\
US - Eurozone (data) & 0.66 & 0.67 & 0.62 & n.a. \\
US - Canada (data) & 0.78 & 0.52 & 0.77 & 0.43 \\
\hline
\end{tabular}

This implies that financial amplification is more pronounced at home than abroad. As a consequence, home output goes up by more than foreign. On the other hand, the responses of land price, household's consumption, and land holdings are almost indistinguishable. An important difference from the symmetric case, though, is that the more leveraged home economy reduces its net foreign asset position by importing financial resources from abroad. As a consequence, the foreign's capital stock goes down on impact, even though investment booms in a persistent way later on, just as in the home economy. With countries that have different levels of financial development, therefore, a reduction in the world interest rate will create credit booms that materialize simultaneously around the world, the effects of which are more pronounced in a more leveraged economy. See also Figure A6.

In Table 3 we report the cross-country correlations generated by the model and by the data, for the case of asymmetric countries. Note that under TFP and interest rate shocks, the correlation of investment across countries is negative due to the responses on impact but becomes positive after. This suggests that investment adjustment costs would improve the model. Here again, global interest rate shocks are essential to generate output co-movement across countries, as depicted in Table 3.

\section{Conclusion}

The contribution of this paper is twofold. First we show that self-fulfilling equilibria occur in a two-country setting where in each country firms can borrow internationally from households, subject to a collateral constraint. Co-movement happens because a lowered interest rate generates credit booms in all countries connected to the world financial market. Because more credit allows firms to expand their scale of operations, a credit boom in each country translates into booming output, investment, consumption, and hours worked. Thus global financial linkages create international synchronization, and financial development means that national economies that are open to cross-border credit flows tend to co-move. In contrast, country-specific shocks to either TFP or to leverage lead to reallocation of world credit resources from one country to another, and as a consequence the home and foreign outputs do not co-move, while consumption does because of international risk-sharing. Second, we show that the model with countries that differ in their levels of financial development can shed light on the reasons why developed economies are not perfectly synchronized.

While in this paper we modestly report qualitative results, a promising avenue for research would be to consider a seriously calibrated version of the model. We believe that the setting outlined in this paper has interesting predictions regarding why developed countries tend to co-move, while they are 
much less synchronized with developing countries. For example, it seems sensible to investigate the pressing issue of global imbalances, for example between the USA and China, through the lens of our stylized model. One important aspect of the results reported above is that net foreign asset positions and trade surpluses can be quite persistent even if short-run variations in the world interest rate are not. This implies, theoretically, that the effects of financial globalization on business-cycle synchronization depend on the level of financial development within countries, in line with recent empirical evidence. In addition, our results suggest that estimating the model against data would reveal that global interest rate shocks are important to explain why output levels co-move internationally.

\section{Appendix A}

\section{Steady state}

Households' Euler equations in both home and foreign countries imply that in the steady state

$$
1+\phi\left(B_{h}-B_{e}\right)=\beta_{h} R^{w}=1+\phi\left(B_{h}^{*}-B_{e}^{*}\right),
$$

which implies

$S=B_{h}-B_{e}=B_{h}^{*}-B_{e}^{*}=S^{*}=0$.

So the steady state is characterized by autarky. Then the Euler equations imply that $R^{w}=\frac{1}{\beta_{h}}$
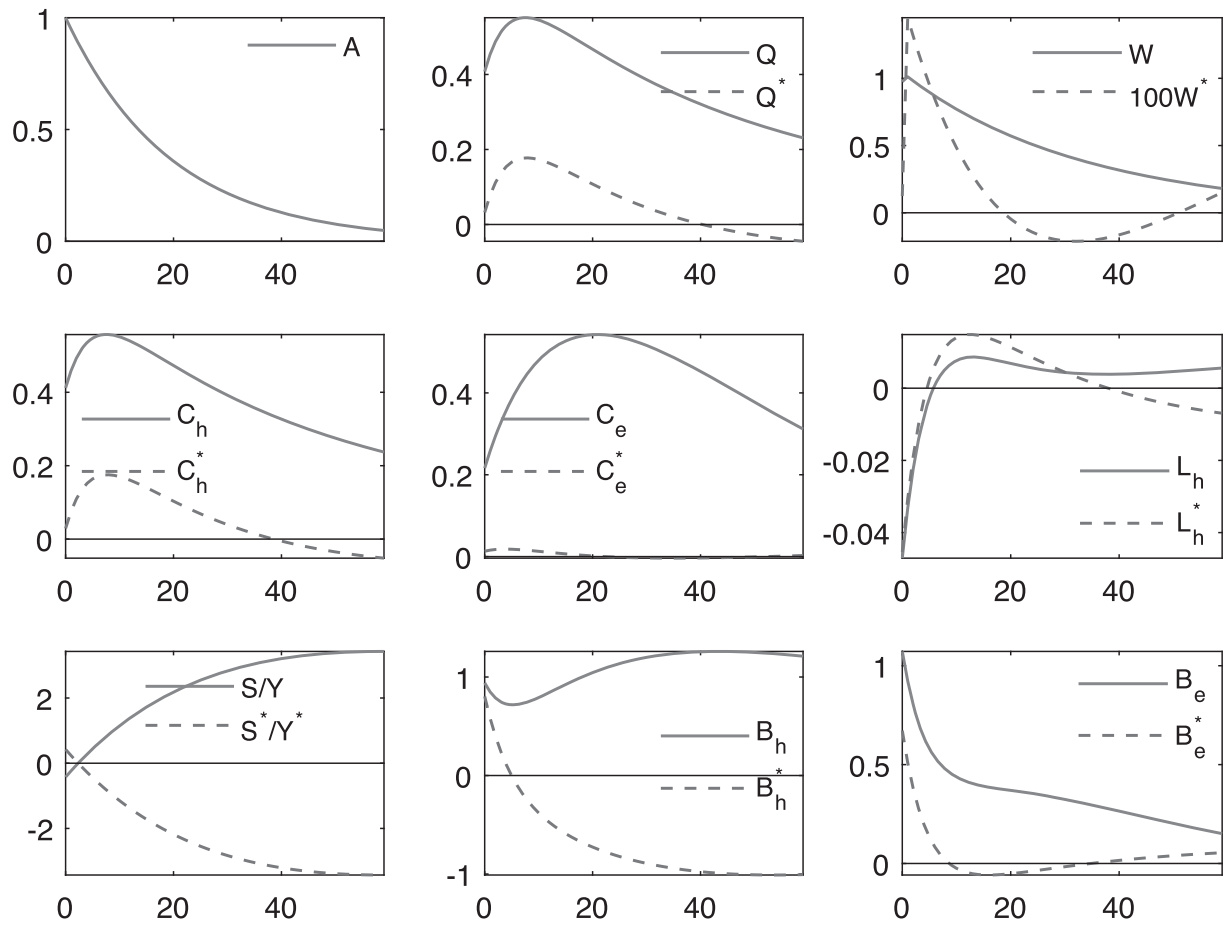

Figure A1 IRFs to a positive TFP shock in the home economy: symmetric countries. 

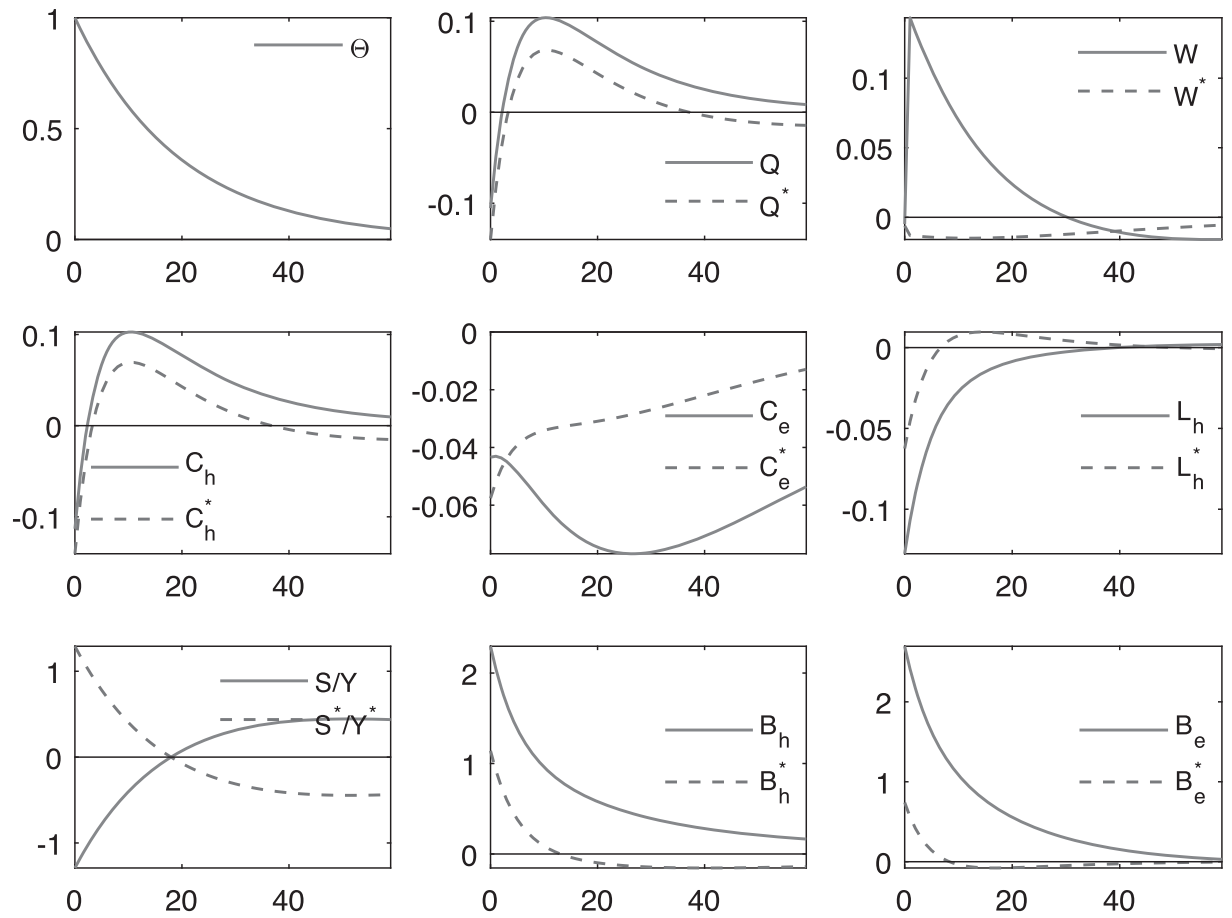

Figure A2 IRFs to a positive leverage shock in the home economy: symmetric countries.
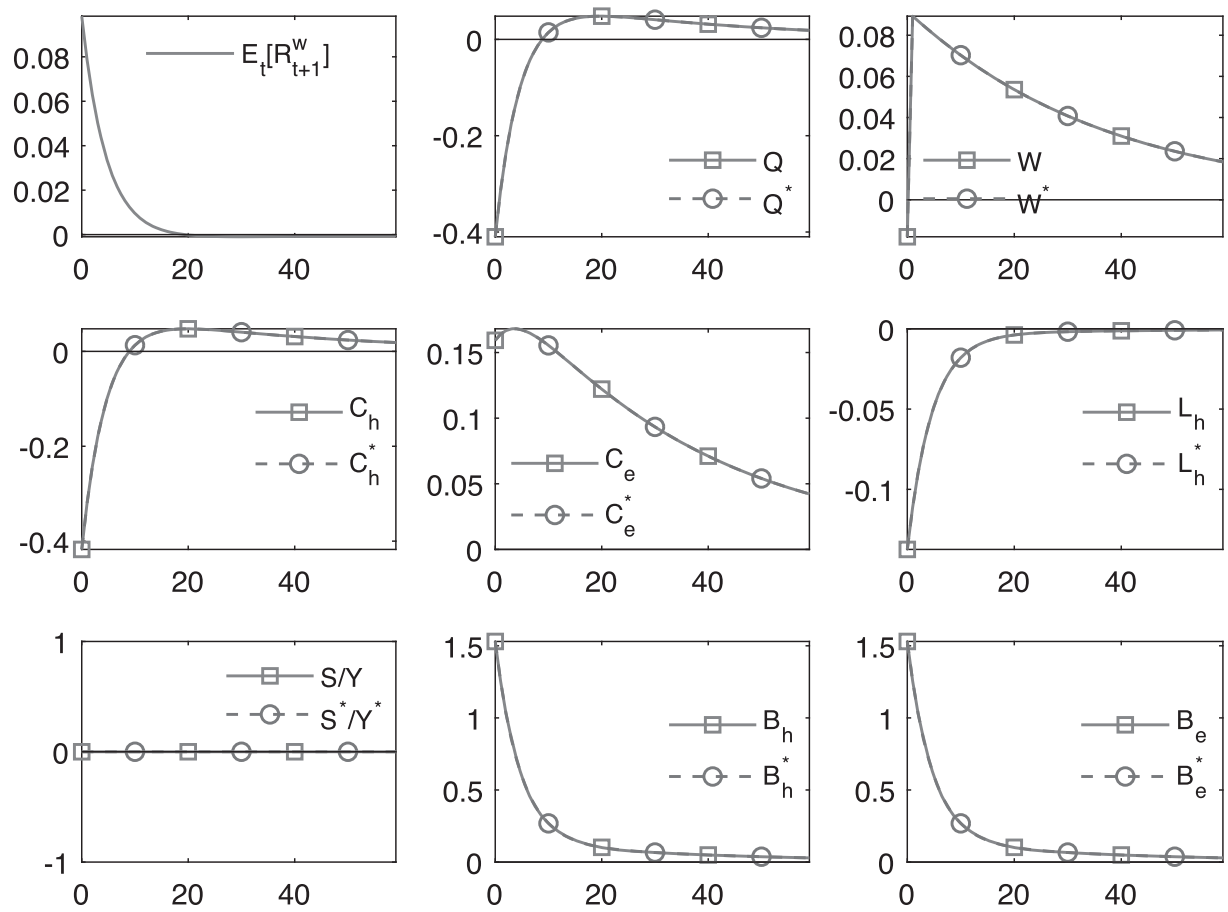

Figure A3 IRFs to a negative shock to the world interest rate: symmetric countries. 

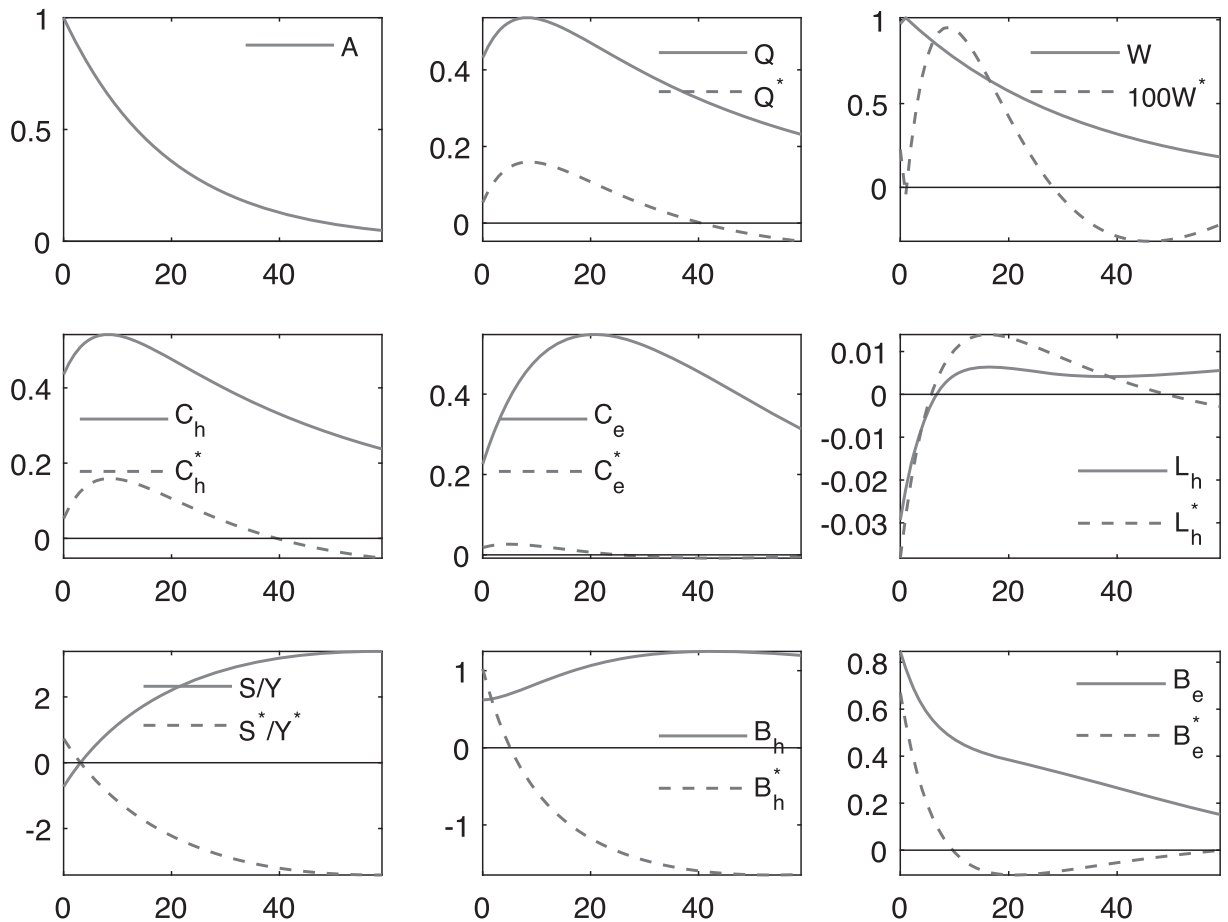

Figure A4 IRFs to a positive TFP shock in the home economy: asymmetric countries.
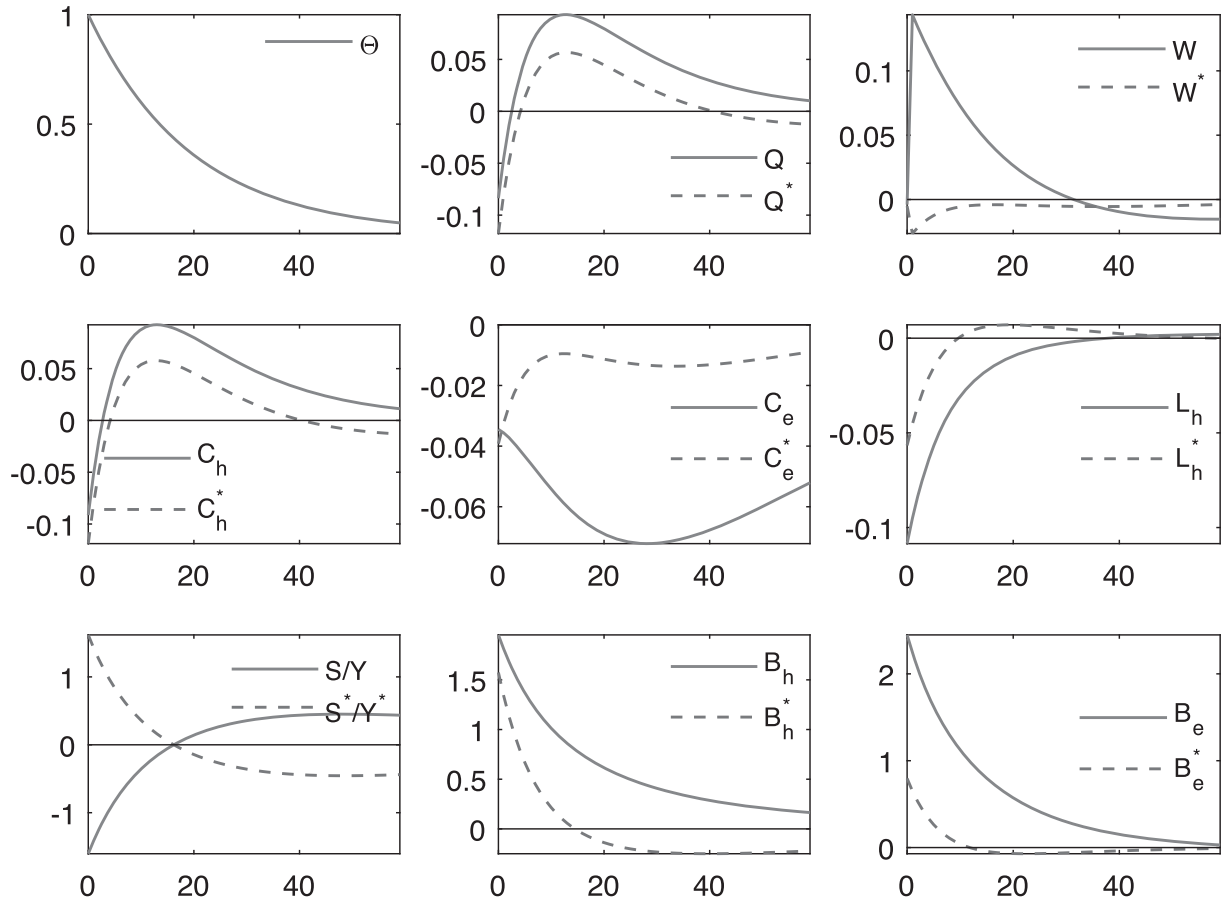

Figure A5 IRFs to a positive leverage shock in the home economy: asymmetric countries. 

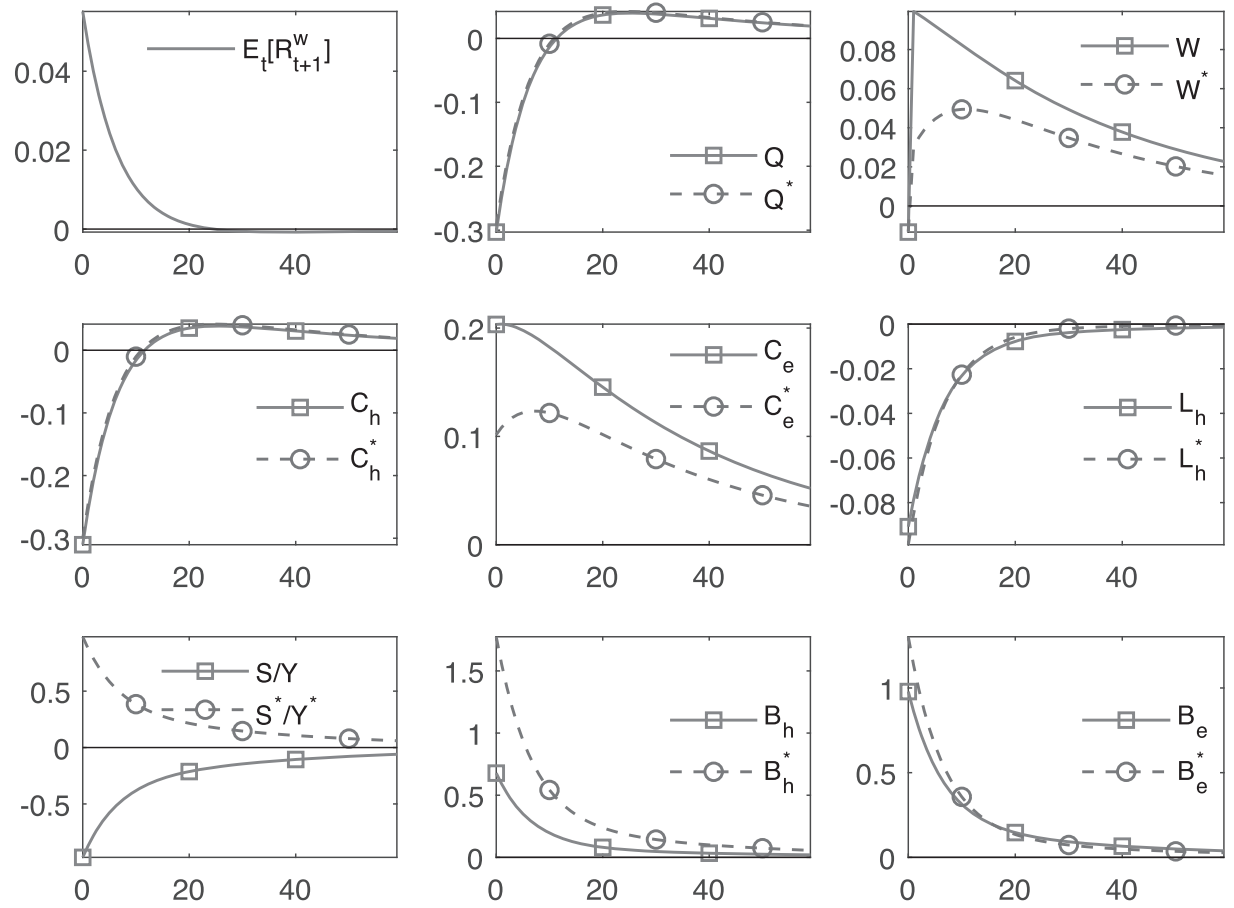

Figure A6 IRFs to a negative shock to the world interest rate: asymmetric countries.

Define lower-case variables as $x \equiv \frac{X}{Y}$ (i.e. the $X$-output ratio). The other equations imply the following conditions:

$$
\begin{aligned}
& \Phi=\left(\beta_{h}-\beta_{e}\right) \Lambda, \\
& Q=\xi \frac{Y}{L_{e}}, \\
& \xi=\frac{\beta \gamma}{1-\left(\Theta \beta_{h}+(1-\Theta) \beta\right)}, \\
& Q=\frac{\beta_{h} \psi c_{h}^{\sigma_{l}} Y^{\sigma_{l}}}{\left(1-\beta_{h}\right)\left(\bar{L}-L_{e}\right)^{\sigma_{w}}}, \\
& b_{e}=\beta_{h} \Theta \xi \\
& k=\frac{\alpha \beta}{1-\beta(1-\delta)}, \\
& W N=(1-\alpha-\gamma) Y, \\
& c_{e}=\alpha+\gamma-\delta k-\left(R^{w}-1\right) b_{e}, \\
& c_{h}=\left(R^{w}-1\right) b_{e}+1-\alpha-\gamma, \\
& \Lambda_{h}=C_{h}^{-\sigma_{l}}, \\
& N=\left(\frac{(1-\alpha-\gamma) Y^{1-\sigma_{l}}}{\zeta c_{h}^{\sigma_{l}}}\right)^{\frac{1}{1+\eta}}, \\
& L_{e}=A^{-\frac{1}{\gamma}} k^{-\frac{\alpha}{\gamma}}\left(\frac{1-\alpha-\gamma}{\zeta}\right)^{-\frac{1-\alpha-\gamma}{\gamma} \frac{1}{1+\eta}} \frac{1-\alpha-\gamma}{\gamma} \frac{\sigma_{l}}{1+\eta} Y^{\frac{1-\alpha-\gamma}{\gamma}} \frac{\sigma_{l}+\eta}{1+\eta}+1 \\
& c_{h}
\end{aligned}
$$


We can solve the steady state $Y$ after plugging $L_{e}$ and $c_{h}$ into the following nonlinear equation:

$$
\frac{\beta_{h} \psi c_{h}^{\sigma_{l}} Y^{\sigma_{l}}}{\left(1-\beta_{h}\right)\left(\bar{L}-L_{e}\right)^{\sigma_{w}}}=\xi \frac{Y}{L_{e}} .
$$

After solving for $Y$, other variables can be solved using the above explicit expressions. The steady-state variables of the foreign country can be solved following the same procedures.

\section{Symmetric countries: Additional IRFs}

Figures A1-A3 report IRFs for the case of symmetric countries, which extend those in Figures 2-4. Note that in all graphs reported here, the solid lines represent the home responses, the grey dashed lines denote the foreign responses.

\section{Asymmetric countries: Additional IRFs}

Figures A4-A6 report IRFs for the case of asymmetric countries, to complement those in Figures 5-7. Note that in all graphs reported here, the solid lines represent the home responses, the grey dashed lines denote the foreign responses.

\section{References}

Azariadis, C., L. Kaas, and Y. Wen (2016), “Self-fulfilling credit cycles,” Review of Economic Studies 83, $1364-405$.

Backus, D., and P. Kehoe (1992), "International evidence on the historical properties of business cycles," American Economic Review 82, 864-88.

Backus, D., P. Kehoe, and F. Kydland (1995), “International business cycles: Theory and evidence,” T. F. Cooley, ed, Frontiers of Business Cycle Research, 331-57, Princeton, NJ: Princeton University Press.

Baxter, M., and M. Crucini (1995), "Business cycles and the asset structure of foreign trade," International Economic Review 36, 821-54.

Benhabib, J., and R. Farmer (1994), "Indeterminacy and increasing returns," Journal of Economic Theory 63, $19-41$.

Benhabib, J., and P. Wang (2013). "Financial constraints, endogenous markups, and self-fulfilling equilibria," Journal of Monetary Economics 60, 789-805.

Boldrin, M., L. Christiano, and J. Fisher (2001), “Habit persistence, asset returns, and the business cycle," American Economic Review 91, 149-66.

Crucini, M., A. Kose, and C. Otrok (2011), “What are the driving forces of international business cycles?” Review of Economic Dynamics 14, 156-75.

Farmer, R., V. Khramov, and G. Nicolò (2015), “Solving and estimating indeterminate DSGE models," Journal of Economic Dynamics and Control 54, 17-36.

He, C., R. Wright, and Y. Zhu (2015), "Housing and liquidity," Review of Economic Dynamics 18, 435-55.

Iacoviello, M. (2005), "House prices, borrowing constraints, and monetary policy in the business cycle," American Economic Review 95(3), 739-64.

Imbs, J. (2004), “ Trade, finance, specialization and synchronization,” Review of Economics and Statistics 86, 723-34.

Kaas, L., P. A. Pintus, and S. Ray (2016), “Land collateral and labor market dynamics in France,” European Economic Review 84, 202-18.

Kiyotaki, N., and J. Moore (1997), “Credit cycles,” Journal of Political Economy 105, 211-48.

Kocherlakota, N. (2000), “Creating business cycles through credit constraints," Federal Reserve Bank of Minneapolis Quarterly Review 24, 2-10.

Kollman, R. (2018), "Explaining international business cycle synchronization: Recursive preferences and the terms of trade channel," mimeo, Université Libre de Bruxelles.

Kose, A., C. Otrok, and C. Whiteman (2003), "International business cycles: World, region, and country-specific factors," American Economic Review 93, 1216-39. 
Kose, A., E. Prasad, and M. Terrones (2003), "How does globalization affect the synchronization of business cycles?" American Economic Review 93, 57-62.

Liu, Z., and P. Wang (2014), “Credit constraints and self-fulfilling business cycles," American Economic Journal: Macroeconomics 6, 32-69.

Liu, Z., P. Wang, and T. Zha (2013). "Land price dynamics and macroeconomic fluctuations," Econometrica 81, $1147-84$.

Miranda-Agrippino, M., and H. Rey (2015), “US monetary policy and the global financial cycle,” NBER Working Paper No. 21722, National Bureau of Economic Research, Cambridge, MA.

Miyamoto, W., and T. Nguyen (2017), "Understanding the cross-country effects of U.S. technology shocks," Journal of International Economics 106, 143-64.

Nishimura, K., and M. Yano (1993), “Interlinkage in the endogenous real business cycles of international economies," Economic Theory 3, 151-68.

Nishimura, K., A. Venditti, and M. Yano (2010), "Expectation driven fluctuations and welfare loss under free trade in two country models," International Journal of Economic Theory 6, 97-125.

Pintus, P. A., and Y. Wen (2013), “Leveraged borrowing and boom-bust cycles," Review of Economic Dynamics 16, 617-33.

Pintus, P. A., Y. Wen, and X. Xing (2016), “The inverted leading indicator property and redistributive effect of the interest rate," Banque de France Working Paper 616.

Schmitt-Grohé, S., and M. Uribe (2003), “Closing small open economy models," Journal of International Economics 61, $163-85$.

Vickery, J. (2008), “How and why do small firms manage interest rate risk?” Journal of Financial Economics 87, 446-70. 